\section{Influence of Seasonality in the Production and Quality of Annona squamosa L. Fruit of Different Sizes}

\author{
Elias A. Moura ${ }^{1}$ \\ Federal University Rural of Semiarid (UFERSA), CEP: 59.625-900, \\ Mossoró, RN, Brazil
}

Pollyana C. Chagas

Federal University of Roraima (UFRR), Campus Cauamé, BR 174, Km 12, Monte Cristo, CEP: 69300-000, Boa Vista, RR, Brazil

Edvan A. Chagas

Brazilian Agricultural Research Corporation (EMBRAPA Roraima), BR 174, Km 8 SN, CEP: 69301-970, Boa Vista, RR, Brazil

\section{Railin R. Oliveira}

Federal University of Roraima (UFRR), Campus Cauamé, BR 174, Km 12, Monte Cristo, CEP: 69300-000, Boa Vista, RR, Brazil

Raphael H. Siqueira

Federal Institute of Education, Science, and Technology of Roraima, Campus Amajari, CEP: 69343-000, Amajari, Roraima, Brazil

Daniel L.L. Taveira

Federal University of Roraima (UFRR), Campus Cauamé, BR 174, Km 12, Monte Cristo, CEP: 69300-000, Boa Vista, RR, Brazil

Wellington F. Araújo and Maria R. Araújo

Federal University of Roraima (UFRR), Campus Cauamé, CEP: 69300-000, Boa Vista, RR, Brazil

\section{Maria L. Grigio \\ Federal University of Roraima (UFRR), Campus Cauamé, BR 174, Km 12, Monte Cristo, CEP: 69300-000, Boa Vista, RR, Brazil}

Additional index words. sugar apple, yield, physicochemical characteristics, postharvest, climate effects

\begin{abstract}
Sugar apple fruit are widely appreciated because of their flavor and functional qualities. However, the final value of the fruit varies according to its physical, physicochemical, and organoleptic qualities. The production and attributes that make up the quality of fruit can be influenced by climatic seasonality in both seasons (dry and wet). Therefore, this work aimed to evaluate whether the production and quality of fruit production of different size classes of $A$. squamosa $\mathrm{L}$. in two seasons are affected by climatic seasonality. The experiment consisted of a randomized block design, with 4 blocks and 10 plants per block. The variables evaluated were number of fruit per hectare, production, and yield. The postharvest evaluation of the fruit consisted of a completely randomized experimental design, in a $3 \times 2$ factorial scheme, which referred to the three sizes and two seasons, and evaluated fruit length and diameter; firmness; fruit, bark, and seed weight; number of seeds; soluble solids; hydrogen ionic potential (pH); titratable acidity (TA); and ratio. The 2014 season had larger fruit in relation to those of the 2015 season; conversely, it showed a lower number of fruit per plant, production, and yield, besides inferior organoleptic quality. Fruit of size class 2 stood out in the 2014 season because of their physical characteristics. However, they had inferior organoleptic quality when compared with fruit of the same size collected during the 2015 season. Fruit of size class $3(\geq 8.1 \mathrm{~cm})$ had greater firmness, providing longer durability and shelf life.
\end{abstract}

Sugar apple (Annona squamosa L.) has been the subject of several studies in recent years as a result of its nutritional, medicinal, and pharmaceutical properties. The most important study fields are agriculture, botany, pharmacology, and chemicals
(Cavalcante et al., 2011; Costa et al., 2015).

The species is of great commercial relevance because of its medicinal and nutritional properties, such as vitamins A, B, C, E, and $\mathrm{K} 1$; antioxidants; polyunsaturated fatty acids; essential minerals; and its pleasant aroma and taste (Liu et al., 2013, 2015). The fruit is consumed mainly in natura; however, it can also be used in the production of juices, sweets, sorbets, liqueurs, and pharmaceutical products (Araújo et al., 2008).

The value of the sugar apple fruit depends on its quality and size. Thus, larger fruit with good visible aspects have a greater market value (Souza et al., 2012). According to Chitarra and Chitarra (2005), the attributes responsible for appearance, flavor, aroma, texture, nutritional value and safety, size, weight, color, firmness, sweetness, acidity, physical and physiologic defects, among others, are part of fruit quality. However, the quality of these attributes also depends on the genetic variability, cultural practices, climatic conditions of the cultivation site, and the incidence of pests and diseases (Araújo et al., 2008).

Depending on the seasonal variations of each biome, the crop may have an early or late cycle. The climate can also affect viability of flower set and the quantity and quality of fruit. George and Nissen (1988) observed that fruiting patterns in Nambour, Queensland, Australia, had significant seasonal variations between and within orchards in the same region. Therefore, this work aimed to evaluate whether the production and quality of fruit production of different size classes of A. squamosa L. in two seasons are affected by the climatic seasonality.

\section{Material and Methods}

Description of the area. The experiment was carried out in a commercial orchard belonging to Paricarana Farm, located in the municipality of Cantá, state of Roraima, Brazil (lat. $2^{\circ} 43^{\prime} 52.5^{\prime \prime} \mathrm{N}$, long. 60³8' $12.1^{\prime \prime} \mathrm{W}$ ). The climate of the region is considered to be Am (tropical humid) according to the Koppen classification, with an average temperature of $27.4{ }^{\circ} \mathrm{C}$ and an altitude of $90 \mathrm{~m}$ (Alvares et al., 2013), a minimum annual rainfall of $944.7 \mathrm{~mm}$, totaling $1678.6 \mathrm{~mm} /$ year, and relative air humidity of $70 \%$ (Araujo et al., 2001).

Plant material. The experiment was performed in an A. squamosa L. orchard and was based on seasonality of two different seasons: 2014 (rainy season) and 2015 (dry season). The experiment included 406 -year-old plants produced from seedlings planted at a $4 \times 4-\mathrm{m}$ spacing, and was conducted in vase form.

Plants were pruned manually using pruning shears. Branches were cut to $40 \mathrm{~cm}$ in length and were pruned manually from the apex to the base to induce a new season. The first production pruning was carried out in Feb. 2014; the second production pruning was performed in Sept. 2014, shortly after the first cycle's harvest.

Weather and soil conditions. The maximum, average, and minimum temperatures, rainfall, and relative humidity were measured throughout the experiment (Fig. 1). The vapor pressure deficit (VPD) was calculated using climatic data (Fig. 2). 


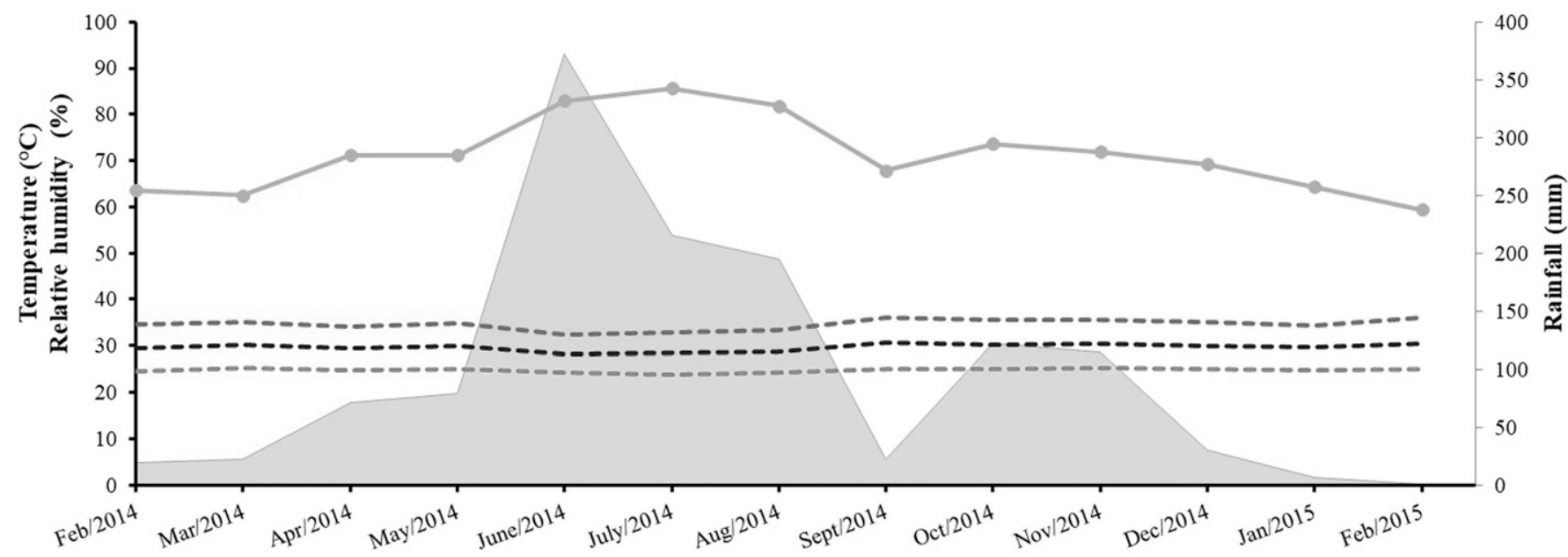

Months

$\mathrm{RF}(\mathrm{mm})$

- - MAXIMUM

--- MINIMUM

- - AVERAGE

$\longrightarrow \mathrm{RH}(\%)$

Fig. 1. Maximum, average, and minimum temperature; rainfall (RF); and relative humidity (RH) for the months evaluated in the experiment.

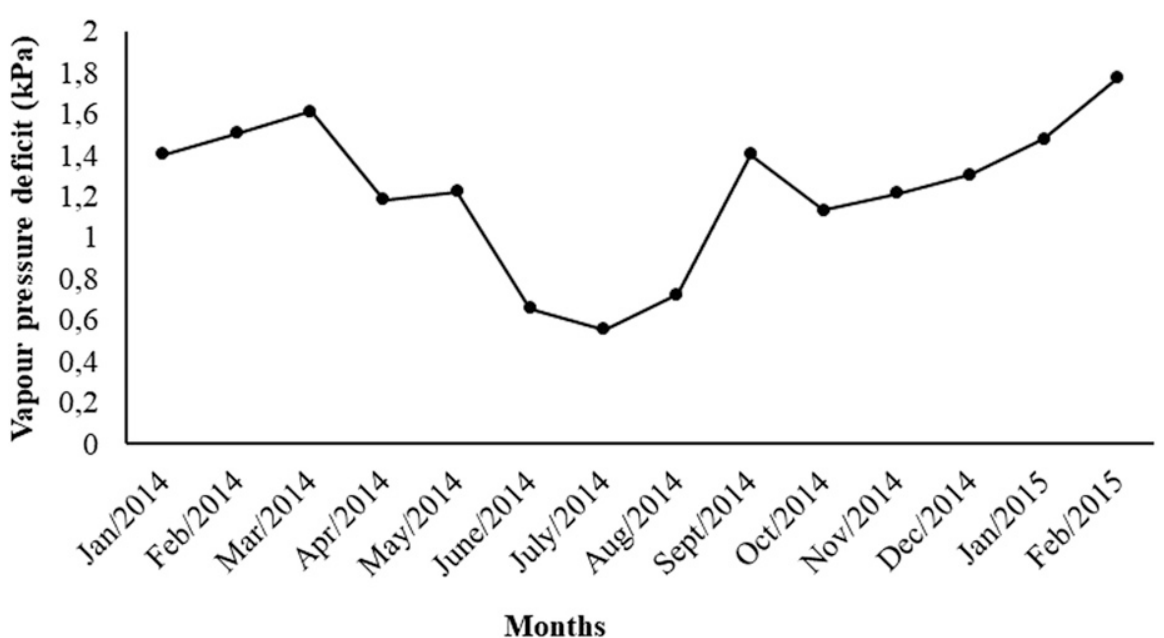

Fig. 2. Vapor pressure deficit for the months evaluated in the experiment.

The soil of the experimental area was classified as Dystrocohesive Yellow Latosol (Santos et al., 2018). The soil chemical attributes are shown in Table 1.

The irrigation system was composed of a conventional sprinkler with a flow rate of $2450 \mathrm{~L} \cdot \mathrm{h}^{-1}$, twice a day, for $30 \mathrm{~min}$. However, irrigation was not performed on rainy days.

Experimental design. The experiment consisted of a completely randomized block design with 4 blocks and 10 plants per block. Conversely, the experimental design adopted

Received for publication 9 Apr. 2019. Accepted for publication 10 Apr. 2019.

We thank the National Council of Scientific and Technological Development (CNPq), the Coordination of Improvement of Higher Education Personnel (CAPES), and the Government of the state of Roraima for financial support and scholarship. ${ }^{1}$ Corresponding author. E-mail: eliasarie190@, gmail.com. pared using Tukey's test, and the probability level for the determination of significance was $P<0.05$. Also, the fruit quality of the different fruit sizes was evaluated by principal component analysis to determine the fruit size with the best qualitative traits in the different seasons. Analyses were performed using the statistical software Sisvar and InfoStat (di Rienzo et al., 2016; Ferreira, 2014).

\section{Results}

Response to seasonal variation in productive performance. The variables number of fruit per hectare, production, and yield showed significant differences by the $\mathrm{F}$ test $(P<0.01)$ in function of seasonality. The 2015 season was superior in relation to the 2014 season, showing the best means for all variables (Table 2).

When comparing the results for all the variables in both seasons, values recorded in the 2015 season were more than twice as much as those recorded for the 2014 season as a result of protogynous dichogamy and the action of pollinating beetles. These factors influence crop production, either individually or combined with climatic factors.

The 2015 season had better climatic conditions, with constant rainfall and higher temperatures, leading to greater production, yield, and number of fruit per plant (Fig. 1). These results suggest that the water blade provided to the crop in the 2014 season did not meet the quantity required by the plant throughout its development in the different phenophases, affecting the product quality and increasing the crop cycle in $17 \mathrm{~d}$.

VPD is one of the climatic factors that most influence $A$. squamosa $\mathrm{L}$. flowers (George and Nissen, 1988). When comparing the first three consecutive months after the production pruning - a crucial moment in which floral development and the action of 
Table 1. Soil chemical analysis of the experimental area in two layers.

\begin{tabular}{|c|c|c|c|c|c|c|c|c|c|c|}
\hline & $\mathrm{pH}$ & & $\mathrm{K}$ & $\mathrm{Ca}^{2+}$ & $\mathrm{Mg}^{2+}$ & $\mathrm{Al}^{3+}$ & $\mathrm{H}+\mathrm{Al}$ & SB & $\mathrm{CECt}$ & \\
\hline Layer (m) & $\mathrm{H}_{2} \mathrm{O}$ & $\mathrm{P}\left(\mathrm{mg} \cdot \mathrm{dm}^{-3}\right)$ & \multicolumn{7}{|c|}{$\mathrm{cmol}_{\mathrm{c}} \cdot \mathrm{dm}^{-3}$} & V $(\%)$ \\
\hline $0-0.20$ & 5.8 & 51.6 & 0.09 & 2.06 & 0.55 & - & 1.7 & 2.7 & 4.4 & 61 \\
\hline $0.20-0.40$ & 5.17 & 0.3 & 0.01 & 0.26 & 0.07 & 0.4 & 2.5 & 0.34 & 2.84 & 12 \\
\hline
\end{tabular}

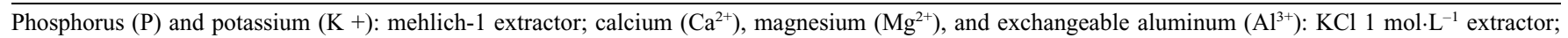
potential acidity $(\mathrm{H}+\mathrm{Al})$ : SMP extractor.

$\mathrm{SB}=$ sum of bases; $\mathrm{CECt}=$ effective cation exchange capacity; $\mathrm{V}=$ base saturation .

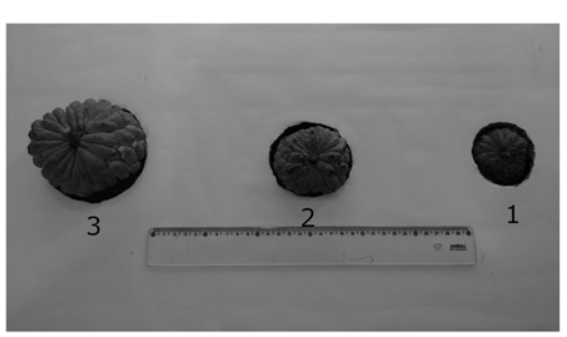

Fig. 3. Classification of sugar apple fruit in three different size classes based on the equatorial diameter of the fruit: 1 , small $(\leq 6 \mathrm{~cm}) ; 2$, medium $(6.1-8.0 \mathrm{~cm})$, and 3 , large $(\geq 8.1 \mathrm{~cm})$.

pollinating beetles occur-between the 2014 and 2015 seasons, the VPD of the former had greater values than the latter (Fig. 2), especially during the second month after production pruning. This period is characterized by intense flower development followed by anthesis.

Thus, the greater the VDP values, the greater is the probability of occurring stigma desiccation before floral dehiscence, given that the flower exhibits protogynous dichogamy. Thus, flower abscission occurs with an increase in VDP.

In our experiment, flowers were pollinated naturally by insects of the family Nitidulidae. Therefore, the population of pollinators in the 2014 season might have been reduced as a result of low rainfall and constant high temperatures in February, March, and April, resulting in an unsuitable environment for both the normal development of the flowers and the activity of the beetles.

Despite the low yield obtained during the 2014 season, the observed mean yield in our experiment was greater than those reported in the literature: $3.2 \mathrm{Mg} \cdot \mathrm{ha}^{-1}$ (Kavati, 1997), 6.05 Mg.ha ${ }^{-1}$ (Kavati and Piza, 1997), 5 $\mathrm{Mg} \cdot \mathrm{ha}^{-1}$ (Costa et al., 2002), and 6.98 $\mathrm{Mg} \cdot \mathrm{ha}^{-1}$ (Patel et al., 2010) without humic substances; and $7.61 \mathrm{Mg} \cdot \mathrm{ha}^{-1}$ with humic substances (Cunha et al., 2015).

Physical, chemical, and physicalchemical characteristics of fruit. Regarding the quality of fruit production, a significant effect was reported at the $1 \%$ probability level $(P<0.01)$ in the seasons $\times$ fruit size interaction for all variables, except for fruit firmness, which exhibited a significant effect only for the factor fruit size at the $5 \%$ probability level by the $\mathrm{F}$ test.

The length and diameter of the fruit showed no differences between the size classes for the 2014 season. Moreover, the means of the 2014 season were greater than those of the 2015 season. For bark firmness, fruit of $8 \mathrm{~cm}$ or larger had the highest mean values; however, fruit 6.1 to $8.0 \mathrm{~cm}$ in size did not differ statistically for this variable. Fruit fresh weight in the 2014 season had greater means in the different sizes, diverging statistically from the 2015 season. During the 2014 season, fruit of size class 6.1 to $8.0 \mathrm{~cm}$ differed statistically only from those of size class $6 \mathrm{~cm}$ or smaller. For the 2015 season, the size class $\geq 8 \mathrm{~cm}$ was superior to the others, showing a statistical difference in fruit weight (Table 3 ).

Fruit production per plant had a significant difference between seasons, resulting in 42.75 and 104.25 fruit/plant in the 2014 and 2015 seasons, respectively. Moreover, the production of the 2015 season had no fruit of class 1 (small), even though the result of production per plant was much greater than that of the previous season.

Fruits of size class $\geq 8 \mathrm{~cm}$ had greater bark firmness $(3.55 \mathrm{~N})$ than the other fruit. These results show that fruit of size class 3 may have a longer shelf life in relation to fruit of size classes $\leq 6 \mathrm{~cm}$ and 6.1 to $8 \mathrm{~cm}(1.21$ and $1.88 \mathrm{~N}$, respectively) (Table 3 ). Sugar apple fruit have a short postharvest life and are highly perishable.

The lower fruit rate of plants of the 2014 season resulted in better fruit development resulting from less competition for photoassimilates, leading to fruit with greater values for length, diameter, and fruit weight (Table 3). This result proves the need for thinning to obtain fruit with a greater final weight.

The variables bark weight, seed weight, and number of seeds were greater for fruit of size class $\leq 6 \mathrm{~cm}$ in the 2014 season when compared with those of the 2015 season. The mean seed weight and the number of seeds in fruit of size class $\geq 8 \mathrm{~cm}$ were greater -15.98 and $46.25 \mathrm{~g}$, respectively-differing statistically from fruit of size classes $\leq 6 \mathrm{~cm}$ and 6.1 to $8 \mathrm{~cm}$. No differences were observed in fruit pulp yield between the 2014 and 2015 seasons and size classes (Table 4).

$\mathrm{TA}, \mathrm{pH}$, and ratio did not differ among fruit size classes in either season. The variable soluble solids did not differ among fruit sizes; however, it exhibited statistical differences within the 2015 season. In this same season, fruit of size class $\geq 8.1 \mathrm{~cm}$ had greater degrees Brix than those of the class 6.1 to $8.0 \mathrm{~cm}$. When comparing the TA of the two seasons, only the variable ratio had no significant differences for the size class $\geq 8.1 \mathrm{~cm}$. The other variables were greater in the 2015 season (Table 5).
$\mathrm{pH}$ measures the degree of acidity of the fruit pulp and can be an indicator of organoleptic quality when associated with other traits, such as soluble solids content. Results showed mean $\mathrm{pH}$ values ranging from 5.03 to 5.7 , indicating the low acidity of sugar apple fruit. Similarly, Silva et al. (2007) reported $\mathrm{pH}$ values ranging from 5.4 to 5.8 , and Hernández et al. (2011) observed pH values from 5.8 to 6.0 , at different harvest times.

Results of TA were within those established as a standard for the species. Gouveia et al., (2007) verified values close to those observed in our experiment, with $0.42 \mathrm{~g}$ citric acid/100 g pulp. Moreover, Dantas (2007) detected values of TA ranging from 0.35 to $0.37 \mathrm{~g}$ citric acid/100 $\mathrm{g}$ pulp. TA acidity is a crucial trait because it is related to appreciation of the fruit in terms of taste and aroma, and its value is used in the norms that establish the quality of the product (Araújo et al., 2008; Chitarra and Chitarra, 2005).

The variable ratio is known as one of the forms for obtaining fruit flavor because it expresses more representative values in the individual evaluation of sugars or acidity (Dantas, 2007). Greater ratio values indicate a more significant presence of the sugar contents than the acid content of the fruit, indicating the sweet predominance of the fruit. Souza (2006) found values ranging from 86.95 to 97.83 in mature fruit.

Principal component analysis of the different seasons (Fig. 4) demonstrated that fruit size presented the best attributes together. Principal component 1 accounted for $60 \%$ of the data, whereas principal component 2 accounted for $17.5 \%$. Therefore, the ranking explained $77.5 \%$ of the size variance in the variables, in the different seasons. A greater correlation was detected for firmness, degrees Brix, and $\mathrm{pH}$ for fruit of size class $\geq 8.1 \mathrm{~cm}$, as in the univariate analysis. Conversely, fruit of size class 6.1 to $8 \mathrm{~cm}$ had a greater relation with fresh weight, yield, and TA. The 2015 season had no fruit of the smaller size and, once again, larger fruit had greater correlations with most variables. The analysis of the ranking allowed separating the groups to predict possible future results consistent with the correlations shown in this study.

\section{Discussion}

Factors that influence productive performance. The occurrence of low rainfall during the first 3 months after production pruning in the 2014 season interfered with plant development. A suitable water blade 
Table 2. Number of fruit per hectare, production, and yield for the 2014 and 2015 seasons of sugar apple, under the savanna conditions, in Roraima.

\begin{tabular}{lccc}
\hline Season & No. of fruit/ha & Production $(\mathrm{kg} / \mathrm{plant})$ & Yield $\left(\mathrm{Mg} \cdot \mathrm{ha} \mathrm{H}^{-1}\right)$ \\
\hline 2014 & $26.72 \mathrm{~b}$ & $8.69 \mathrm{~b}$ & $5.43 \mathrm{~b}$ \\
2015 & $65.16 \mathrm{a}$ & $18.92 \mathrm{a}$ & $11.82 \mathrm{a}$ \\
$\mathrm{CV}$ & 16.71 & 15.79 & 15.79 \\
\hline
\end{tabular}

Means followed by the same lowercase letter in the column do not differ from each other by Tukey's test at $P<0.05$.

Table 3. Length, diameter, firmness, and weight of fruit in the different size classes.

\begin{tabular}{|c|c|c|c|c|c|c|c|c|}
\hline \multirow{2}{*}{ Season } & \multicolumn{3}{|c|}{ Length (mm) } & & \multicolumn{3}{|c|}{$\operatorname{Diam}(\mathrm{mm})$} & \multirow{2}{*}{ Mean } \\
\hline & \multicolumn{3}{|c|}{ Size $^{\mathrm{z}}(\mathrm{cm})$} & & \multicolumn{3}{|c|}{ Size $(\mathrm{cm})$} & \\
\hline 2014 & $75.79 \mathrm{~A}$ & $79.63 \mathrm{aA}$ & $76.3 \mathrm{aA}$ & 77.24 & $82.45 \mathrm{~A}$ & $85.61 \mathrm{aA}$ & $86.36 \mathrm{aA}$ & 84.8 \\
\hline Mean & 75.79 & 72.54 & 72.56 & - & 82.45 & 75.57 & 78.86 & - \\
\hline \multirow[t]{3}{*}{$\mathrm{CV}(\%)$} & \multicolumn{4}{|c|}{7.56} & \multicolumn{3}{|c|}{6.79} & \\
\hline & \multicolumn{3}{|c|}{ Firmness $(\mathrm{N})$} & & \multicolumn{3}{|c|}{ Fruit weight $(\mathrm{g})$} & \\
\hline & \multicolumn{3}{|c|}{ Size $(\mathrm{cm})$} & & \multicolumn{3}{|c|}{ Size $(\mathrm{cm})$} & \\
\hline 2014 & 2.41 & 2.02 & 3.99 & $2.81 \mathrm{a}$ & $233.88 \mathrm{~B}$ & $274.22 \mathrm{aA}$ & $251.40 \mathrm{aAB}$ & 253.16 \\
\hline 2015 & - & 1.73 & 3.12 & $2.43 \mathrm{a}$ & - & $151 \mathrm{bB}$ & 213.75 bA & 182.37 \\
\hline Mean & 2.41 & $1.88 \mathrm{AB}$ & $3.55 \mathrm{~A}$ & - & 233.88 & 212.61 & 232.58 & - \\
\hline CV $(\%)$ & \multicolumn{4}{|c|}{63.69} & \multicolumn{4}{|c|}{10.17} \\
\hline
\end{tabular}

${ }^{\mathrm{z}} 1=\operatorname{small}(\leq 6 \mathrm{~cm}) ; 2=$ medium $(6.1-8.0 \mathrm{~cm}) ;$ and $3=$ large $(\geq 8.1 \mathrm{~cm})$, in function of seasonality, under savanna conditions in Roraima.

Means followed by the same lowercase letters in the columns and uppercase letters in the rows do not differ from each other by Tukey's test at the $5 \%$ probability level.

Table 4. Bark weight, seed weight, seed number, and pulp yield of fruit of different size classes.

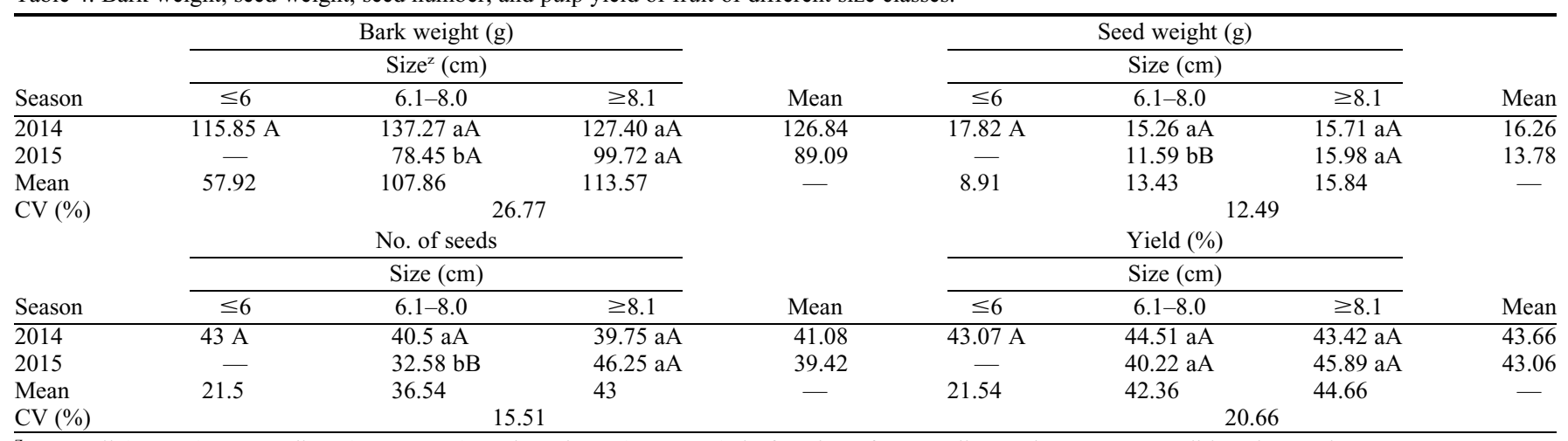

${ }^{\mathrm{z}_{1}}=\operatorname{small}(\leq 6 \mathrm{~cm}) ; 2=$ medium $(6.1-8.0 \mathrm{~cm}) ;$ and $3=$ large $(\geq 8.1 \mathrm{~cm})$, in function of seasonality, under savanna conditions in Roraima.

Means followed by the same lowercase letters in the columns and uppercase letters in the rows do not differ from each other by Tukey's test at the $5 \%$ probability level.

Table 5. Unfolding of the interaction of the variables soluble solids (SS), hydrogen ionic potential (pH), titratable acidity (TA), and ratio of fruit of different size classes.

\begin{tabular}{|c|c|c|c|c|c|c|c|c|}
\hline \multirow[b]{3}{*}{ Season } & \multicolumn{3}{|c|}{ SS $\left({ }^{\circ}\right.$ Brix $)$} & & \multicolumn{3}{|c|}{$\mathrm{pH}$} & \multirow[b]{3}{*}{ Mear } \\
\hline & \multicolumn{3}{|c|}{$\operatorname{Size}^{\mathrm{z}}(\mathrm{cm})$} & & \multicolumn{3}{|c|}{ Size $(\mathrm{cm})$} & \\
\hline & $\leq 6$ & $6.1-8.0$ & $\geq 8.1$ & Mean & $\leq 6$ & $6.1-8.0$ & $\geq 8.1$ & \\
\hline 2014 & $26.07 \mathrm{~A}$ & $25.93 \mathrm{bA}$ & $27.20 \mathrm{bA}$ & 26.4 & $5.03 \mathrm{~A}$ & $5.02 \mathrm{bA}$ & $5.04 \mathrm{bA}$ & 5.03 \\
\hline Mean & 26.07 & 27.91 & 30.15 & - & 5.03 & 5.41 & 5.38 & - \\
\hline \multirow[t]{2}{*}{ CV $(\%)$} & & & & & \multirow{2}{*}{\multicolumn{3}{|c|}{2.95}} & \\
\hline & \multicolumn{3}{|c|}{ TA (g citric acid/100 g pulp) } & & & & & \\
\hline 2014 & $0.39 \mathrm{~A}$ & $0.39 \mathrm{bA}$ & $0.46 \mathrm{aA}$ & 0.41 & $66.82 \mathrm{~A}$ & $68.33 \mathrm{aA}$ & $62.11 \mathrm{aA}$ & 65.75 \\
\hline 2015 & - & $0.48 \mathrm{aA}$ & $0.50 \mathrm{aA}$ & 0.49 & - & $62.13 \mathrm{aA}$ & $66.47 \mathrm{aA}$ & 64.3 \\
\hline Mean & 0.39 & 0.44 & 0.48 & - & 66.82 & 64.28 & 65.23 & - \\
\hline CV (\%) & \multicolumn{3}{|c|}{15.07} & & \multicolumn{3}{|c|}{12.82} & \\
\hline
\end{tabular}

${ }^{\mathrm{z}} 1=$ small $(\leq 6 \mathrm{~cm}) ; 2=$ medium $(6.1-8.0 \mathrm{~cm}) ;$ and $3=$ large $(\geq 8.1 \mathrm{~cm})$, in function of seasonality, under savanna conditions in Roraima.

Means followed by the same lowercase letters in the columns and uppercase letters in the rows do not differ from each other by Tukey's test at the $5 \%$ probability level.

for the plant to complete the vegetative and reproductive stages is crucial during this period. Adequate water supply to the plant is related to maintenance of tissue turgor, which is essential for photosynthesis, flowering, and fruiting (Floss, 2008).
A. squamosa L. has hermaphrodite flowers with protogynous dichogamy (Thakur and Singh, 1965). Flowers are pollinated by 


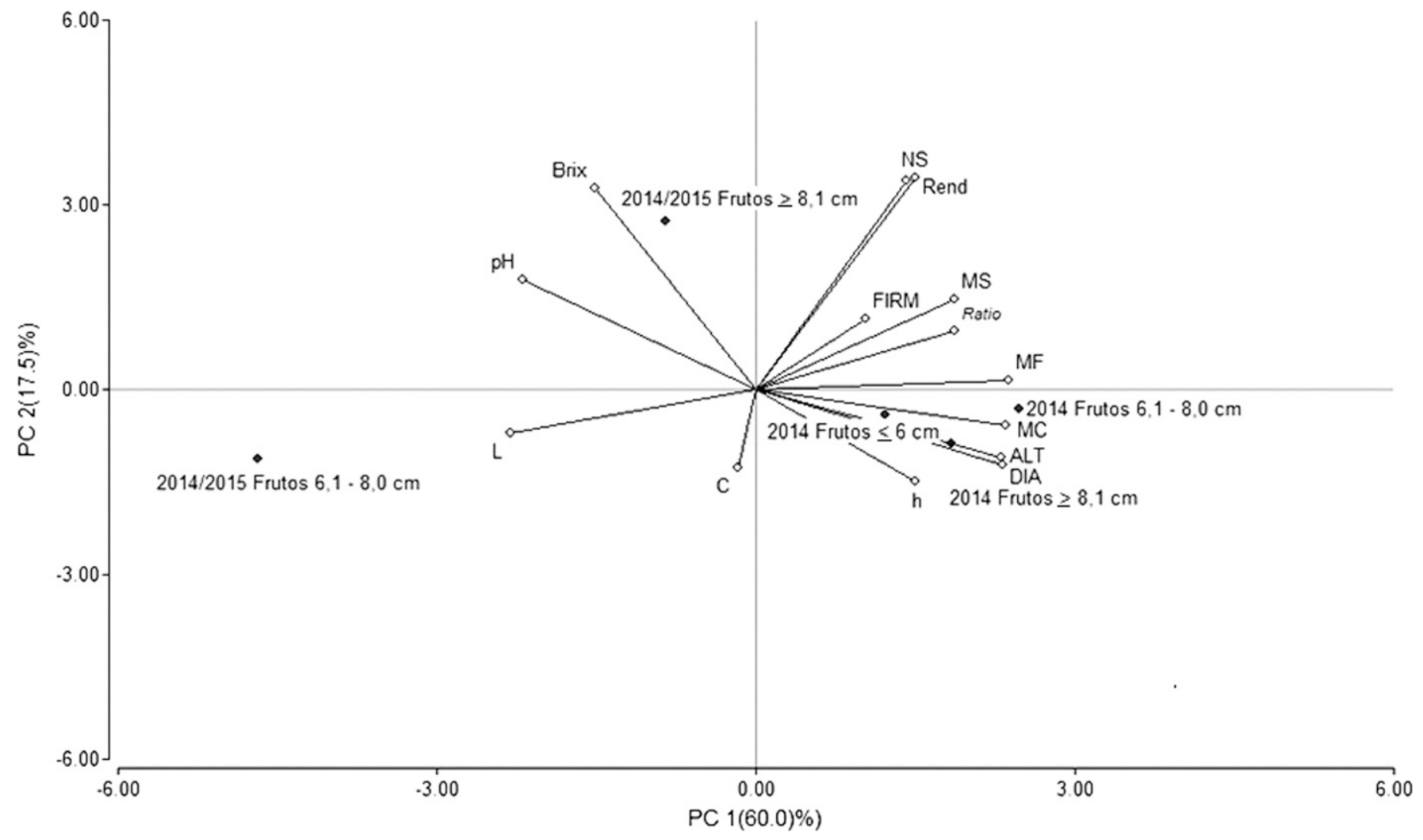

Fig. 4. Principal component (PC) analysis in the 2014 and 2015 seasons for different fruit sizes of sugar apples for the variables firmness (Firm), soluble solids (measured in degrees Brix), hue angle (h), diameter (Dia), bark weight (BM), fruit weight (FM), yield, fruit height (Alt), ratio, number of seeds (NS), seed weight (SM), luminosity (L), chromaticity $(\mathrm{C})$, and hydrogen ionic potential ( $\mathrm{pH})$.

insects of the family Nitidulidae, which are pollinator agents of the species. However, these beetles require favorable environmental conditions for efficient pollination. Artificial pollination is also possible, and this technique is widely used in commercial orchards for providing regular fruit with uniform diameter resulting from the complete pollination of all ovaries. Nevertheless, for good production in both pollination forms, a suitable environment is required for the development of the flower. This process is strongly influenced by climatic factors.

George and Nissen (1988) observed that soil water stress reduced the fruit yield of the hybrid cultivar African Pride (Annona cherimólia $\times$ Annona squamosa) significantly under high-temperature conditions. They also reported that the greater the VPD, the greater the reduction in the number of fruit of both naturally and artificially pollinated plants. In addition, they reported a significant reduction in the number of flowers that reached anthesis as a result of floral abscission and stigma desiccation caused by high VPD $(3.0 \mathrm{kPa})$ at the flowering stage.

George et al. (1989) obtained similar results for the beetles of the family Nitidulidae. The authors reported a reduction in the insect population under both high- and lowrainfall conditions, and an increase in the activity of the beetle in the flower with an increase in soil temperature. According to Schmidt (1935), beetles perform massed flights when the soil temperature is very high.
Kishore et al. (2012) analyzed the visitation frequency of the pollinating agents Carpophilos domidiatus and Carpophilos hemipterous of the family Nitidulidae in $A$. squamosa L. flowers and detected seasonal and climatic variations. According to the authors, the visitation frequency of both species in September was significantly greater in relation to April. Although our study did not count the beetle population, the periods when the flowers were ready for anthesis were similar.

Effect of quality of fruit. The higher value of fruit weight obtained in the 2014 season was a result of low fruit production. This phenomenon is related to the redistribution of photoassimilates in the plant. Souza (2006) studied the number of fruit per plant in sugar apple and verified that, based on economic analysis, the best yield is obtained when the fruit load occurs in $\approx 30 \%$ of the branches.

Although the 2015 season had a lower mean of fruit per plant than the 2014 season, the mean values for this variable were within those observed by Costa et al. (2002), Junqueira et al. (2003), Nietsche et al. (2008), and da Silva et al. (2002).

According to Goñi et al. (2010), the loss of firmness is one of the most relevant factors in fruit quality depreciation postharvest. Chitarra and Chitarra (2005) state that a steady reduction in firmness begins with normal fruit maturation, which leads to loss of cell turgor and reduction in fruit size by the action of hydrolytic enzymes and nonenzymatic mechanisms. Therefore, fruit of size class $\geq 8 \mathrm{~cm}$ have better market characteristics, which allow better fruit transportation and a longer commercialization period than the other size classes. This result is a result of the greater firmness of the fruit, which provides a longer postharvest life.

The values found in our study demonstrate the relationship between fruit weight, bark weight, seed weight, and fruit size. Silva et al. (2007) reported a much greater variation in bark weight and seed weight, which ranged from 167.64 to $193.76 \mathrm{~g}$ and from 25.82 to $27.79 \mathrm{~g}$, respectively. These results are related closely to pulp yield, with expressive results for the different seasons in the three size classes, and the means were similar to those found by Silva et al. (2007) (40.08 g).

The values for soluble solids content were consistent with those reported in the literature. Pereira et al. (2010) obtained soluble solids content between 19.32 and $29^{\circ}$ Brix; Silva et al. (2007) detected soluble solids content between 25.10 and $27.71^{\circ}$ Brix; and Pereira et al. (2003) reported soluble solids content between 25.48 and $27.52^{\circ}$ Brix.

Soluble solids content can be influenced by several factors, such as plant genetics, chemical and organic fertilization, irrigation, and temperature (Junqueira and Junqueira, 2014). In general, soluble solids content of the fruit produced during the two seasons (2014 and 2015) had high means, showing the quality of fruit produced in the savanna environment, in the state of Roraima. These 
results are confirmed by comparing the contents of soluble solids with the low TA, expressing the sweetness of the fruit.

\section{Conclusion}

Seasonality affects yield and fruit quality of $A$. squamosa L. The dry season is more detrimental to production. Fruit of size class $\geq 8 \mathrm{~cm}$ are more desirable in both seasons because of their greater firmness, which provides longer durability and longer postharvest shelf life.

\section{Literature Cited}

Alvares, C.A., J.L. Stape, P.C. Sentelhas, J.L. de Moraes Gonçalves, and G. Sparovek. 2013. Köppen's climate classification map for Brazil. Meteorol. Z. (Berl.) 22:711-728.

Araujo, W.F., A.S. de Andrade Junior, R.D. de Medeiros, and R.A. Sampaio. 2001. Precipitação pluviométrica mensal provável em Boa Vista, estado de Roraima, Brasil. Rev. Bras. Eng. Agr. Ambient. 5:563-567.

Araújo, J.F., S. Leonel, and J.P. Neto. 2008. Organomineral and liquid biofertilization in sugar apple fruit. Biosci. J. 24:48-57.

Cavalcante, I.H.L., M.C.S. Moura, L.F. Rocha, G.B. Silva Júnior, L.V. Martins, and R.R.S. Silva. 2011. Seleção preliminar de genótipos de pinheira em Bom Jesus-PI. Rev. Ciênc. Agrár. $34: 173-181$

Chitarra, M.I.F. and A.B. Chitarra. 2005. Póscolheita de frutas e hortaliças: fisiologia e manuseio, 2nd ed. Universidade Federal de Lavras, Lavras, Minas Gerais - Brasil.

Costa, S.L.D., A.J.C.D. Carvalho, P.G.D.O. Pessanha, P.H. Monnerat, and C.S. Marinho. 2002. Produtividade da cultura da pinha (Annona squamosa L.) em função de níveis de adubação nitrogenada e formas de aplicação de boro. Rev. Bras. Frutic. 24:543-546.

Costa, E.V., M.F.C. Sampaio, M.J. Salvador, A. Nepel, A. Barison, E.V. Costa, M.F.C. Sampaio, M.J. Salvador, A. Nepel, and A. Barison. 2015. Chemical constituents from the stem bark of Annona pickelii (Annonaceae). Quim. Nova 38:769-776.

Cunha, M. dos S., Í.H.L. Cavalcante, A.C. Mancin, F.G. Albano, and A.S. Marques. 2015. Impact of humic substances and nitrogen fertilising on the fruit quality and yield of custard apple. Acta Sci. Agron. 37:211-218.

Dantas, T.M. 2007. Conservação pós-colheita de pinha, fruta-do-conde ou ata (Annona squamosa L.) utilizando 1-metilciclopropeno sob refrigeração associado à atmosfera modificada. Universidade Federal do Ceará, Centro de Ciências Agrárias, Dissertação mestrado.

da Silva, J., E. da Silva, and P.S.L. Silva. 2002. Determinação da qualidade e do teor de sólidos solúveis nas diferentes partes do fruto da pinheira (Annona squamosa L.). Rev. Bras. Frutic. 24:562-564.

di Rienzo, J.A., F. Casanoves, M.G. Balzarini, L. Gonzalez, M. Tablada, and C.W. Robledo. 2016. InfoStat versión 2016. Grupo InfoStat, FCA, Universidad Nacional de Córdoba, Argentina. 30 Oct. 2018. <http://www.infostat. com.ar/index.php?mod=page $\&$ id=15>.

Ferreira, D.F. 2014. Sisvar: A guide for its bootstrap procedures in multiple comparisons. Cienc. Agrotec. 2(38):109-112.

Floss, E.L. 2008. Fisiologia das plantas cultivadas: O estudo do que está por trás do que se vê. 4 th ed. Universidade Federal de Passo fundo, Passo Fundo, Rio Grando do Sul - Brasil.

George, A.P. and R.J. Nissen. 1988. The effects of temperature, vapor pressure deficit and soil moisture stress on growth, flowering and fruit set of custard apple (Annona cherimola $\times$ Annona squamosa) 'African Pride'. Scientia Hort. 34:183-191.

George, A.P., R.J. Nissen, D.A. Ironside, and P. Anderson. 1989. Effects of nitidulid beetles on pollination and fruit set of Annona spp. hybrids. Scientia Hort. 39:289-299.

Goñi, O., M.T. Sanchez-Ballesta, C. Merodio, and M.I. Escribano. 2010. Ripening-related defense proteins in Annona fruit. Postharvest Biol. Technol. 55:169-173.

Gouveia, D.S., M.E.R.M.C. Mata, M.E.M. Duarte, A.J.M. Queiroz, and S.M.P. Ugulino. 2007. Avaliação físico-química e aceitação sensorial do suco de pinha e do blend pinha-leite. Rev. Bras. Prod. Agroindustriais 9:29-36.

Hernández, O., I. Urdaneta, M. Morón, C. Hernández, J. Chacín, R. Guerrero, and C. Clamens. 2011. Caracterización fisicoquímica de frutos de riñon (Annona squamosa L.) bajo condiciones de riego por gravedad. Rev. Fac. Agron. 28:351-358.

Junqueira, N.T.V. and K.P. Junqueira. 2014. Major diseases of Annonaceae in Brazil: Description and control. Rev. Bras. Frutic. 36:55-64.

Junqueira, R.M., R.G.T. Ribas, E.A. Lima, F.L.D.O Lima, J.G.M. Guerra, D.L. Almeida, R.N.B. Busquet, and R.D.L.D Ribeiro. 2003. Efeito da cobertura viva de solo com cunhã (Clitoria ternatea L.) e da polinização artificial na produtividade da pinha (Annona squamosa L.) sob manejo orgânico. Agron. Seropédica 37:71-76.

Kavati, R. 1997. Melhoramento em fruta-doconde, p. 47-54. In: A.R. São José, I.V.B. Souza, O.M. Morais, and T.N.H. Rebouças. Anonáceas, produção e mercado (Pinha, Graviola, Atemóia e Cherimólia). DFZ/UESB, Vitória da Conquista, BA.

Kavati, R. and J.R.C. Piza. 1997. Formação e manejo do pomar de fruta-do-conde, atemóia e cherimólia, p. 75-83. In: A.R. São José, I.V.B. Souza, O.M. Morais, and T.N.H. Rebouças (eds.). Anonáceas, Produção e Mercado (Pinha, Graviola, Atemóia e Cherimólia). DFZ/UESB, Vitória da Conquista-BA.
Kishore, K., A.K. Shukla, N. Babu, D.N. Sarangi, and S. Patanayak. 2012. Pollination biology of Annona squamosa L. (Annonaceae): Evidence for pollination syndrome. Scientia Hort. 144:212-217.

Liu, K., H. Li, C. Yuan, Y. Huang, Y. Chen, and J. Liu. 2015. Identification of phenological growth stages of sugar apple (Annona squamosa L.) using the extended BBCH-scale. Scientia Hort. 181:76-80.

Liu, K., C. Yuan, and G. Jing. 2013. Effect of exogenous oxalic acid treatment on ripening and preservation of Annona squamosa L. fruit during postharvest storage. Food Sci. 14:329334.

Nietsche, S., M.C.T. Pereira, N.N. Durães, M.V. Rocha, F.A. Santos, F.S. Santos, C.F. Nunes, and L. de M.V. da Cunha. 2008. Qualidade físico-química de frutos de pinheira ensacados. Unimontes Científica 6:141-144.

Patel, N.M., D.K. Patel, L.R. Verma, and M. Patel. 2010. Effect of cultural and chemical treatments on fruit set and fruit yield of custard apple (Annona squamosa Linn.) cv. Sindhan. J. Asiático Hort. 5:498-502.

Pereira, M.C.T., L.C. Braz, S. Nietsche and W.F. da Mota. 2010. Determining the harvesting maturity of the sugar apple fruits on northern Minas Gerais. Acta Hort. 207-214.

Pereira, M.C.T., S. Nietsche, F.S. Santos, A.A. Xavier, L. de M.V. da Cunha, C.F. Nunes, and F.A. Santos. 2003. Efeito de horários de polinização artificial no pegamento e qualidade de frutos de pinha (Annona squamosa L.). Rev. Bras. Frutic. 25:203-205.

Santos, H.G. dos, P.K.T. Jacomine, L.H.C. dos Anjos, V.A. de Oliveira, J.F. Lumbreras, M.R. Coelho, J.A. de Almeida, J.C. de Araujo Filho, J.B. de Oliveira, and T.J.F. Cunha. 2018. Brazilian Soil Classification System. 5th ed. rev. and exp. Embrapa, Brasília. DF.

Schmidt, C.T. 1935. Biological studies on the nitidulid beetles found in pineapple fields (Nitidulidae, Coleoptera). Ann. Entomol. Soc. Amer. 28:475-511.

Silva, J.C.G., M.A. Chaves, A.R. São José, T.N.H. Rebouças, and J.F.T. Alves. 2007. The influence of mulching in relation to physical and chemical characteristics of the sugar apple (Annona squamosa L.). Rev. Bras. Frutic. 29:287-291.

Souza, I.V.B. 2006. Produção comercial de pinheira. Universidade Estadual do Sudoeste da Bahia, Programa de Pós-Graduação em Agronomia, Campus de Vitória da Conquista, Dissertação mestrado).

Souza, I.V.B., A.R. São José, T.N.H. Rebouças, M.M. Pires, O.M. Morais, A.E.S. Viana, N.O Dias, and M.P. Bomfim. 2012. Efeito do debaste de frutos na produção e comercialização da pinha 24:88-89.

Thakur, D.R. and R.N. Singh. 1965. Studies on pollen morphology, pollination and fruit set in some Annonas. Indian J. Hort. 22:10-18. 